\title{
Capitalism: 50 Ideas You Really Need to Know
}

\section{Attaullah Hazrat}

Lovely Professional University, Phagwara, India

\section{Book Review}

You won't be able to understand capitalism without understanding economics as it's very clear that Capitalism is annoying and often confusing word. It tends to call upon to mind a $19^{\text {th }}$ century power resist between owners of capital - factories and machines - and those who owned nothing more than their own labor. But that is not really the kind of world we live in anymore. Capital is no longer necessarily something that will kill you if it falls on you. In reality, some of the most valuable forms of capital in the world today are actually intangible things like algorithms, brands or the agglomeration of skills and experience in an individual company. And those with economic power no longer need own much capital. Some employees are far more influential than the nominal owners of the firm's capital, the dispersed shareholder register. As the writer has argued "modern market economy" would be a more useful description of the kind of society in which most of us in the West exist than "capitalist". Yet the word capitalism has stuck. But capitalism is private ownership of the means of production. And as the first part of the book is talking about the basic concepts so coming upon to property rights as it is a creation of government, if government is to provide protections for property, then it needs a source of revenue, and the ability to coerce citizens into providing that revenue.

Free Market seems to have strong attractions from both a philosophical and a practical economic perspective. On philosophical grounds, surely human freedom is maximized if we do not control what people can make, buy and sell, except where it is necessary to protect public safety. And Karl Marx's fundamental insight into the capitalist system was twofold.

First, author realized that in a capitalist society, firm owners will seek to maximize their profits by paying workers as little as possible. And second, author saw it was this surplus value, not paid out to the workers, that was therefore available to be reinvested in the firm. And also author has discussed about money, its money if you think it is. Money is deemed necessary because of three reasons first as a medium of exchange, second as a unit of value, third as a store of value. And taking to monopoly from an economic perspective, the main reason that monopolies emerge is the increasing returns to scale that is, larger firms are likely to be more efficient. Competition will therefore mean that larger firms will drive smaller ones from the market.

And the second part of the book is all about the institutions of capitalism which author has started from entrepreneurs to trade unions, the duty of the entrepreneur in the capitalist system is to take risks, with their own time or money, in order to convert a new idea into profitable business opportunity. Without entrepreneurs, an idea might never become a product. And the idea about banks, Most of the economists see modern banks as playing three main roles in the economy: as in intermediary between saving and investment: as a means of mediating between timeframes for savings and loans; and as a way of creating money itself. And the most important is about the role of the government, the state would simply provide a legal and judicial framework to define and enforce the property rights essential for a capitalist economy to function, with anything else seen as an infringement of liberty. To make it much simple we can say that the government has an essential role in economic development. Although in principle Smith disapproved of any interference with the market mechanism, author was fundamentally sympathetic to the workers.

In the third part of the book author has compiled all about the finance and financial markets which author has started from stock market and ended with debt, stock market fulfill directly two key functions in a capitalist economy. They allow companies to raise capital for investment by issuing and selling shares to the public's and they then allow the purchasers of those shares to resell them. As it is the simple version, but today's financial system is much, much more than just banks and stock markets. It includes insurance companies and pension funds, mortgage markets, and the whole of what is called the Shadow banking system which loosely refers to any financial intermediary that channels money from lenders to borrowers but isn't a bank.

At any given time, some of us want to spend more than we earn, while others are earning more than we spend, sour saving are mostly held in banks and pension funds, and these are lent to companies to invest, to individuals to buy houses, and to government in order to finance that part of their spending that they do not cover by rising taxes.

And under The political economy author has discussed from democracy to the globalization; democracy and capitalism advanced further in the second half of the $20^{\text {th }}$ century. Spain and Portugal, the remaining dictatorships of Western Europe, became democratic in the 1970s, and then in 1989 the fall of the Berlin wall was followed by a surprisingly quick economic and political transition in Eastern Europe. and they also discussed about the freedom of market and order and tradition, and on the other corner of the same part author also talked about the socialism and the benefit of the socialism to the new world and the benefit of the globalization to the developing and developed countries and will always lead the nations to the better place. Exactly the writer talked about keeping up with the joneses as well in this part.

Future of the capitalism, since the financial crisis of 2008-09, most advanced economies have seen a painfully slow recovery so I can say that stagnation is exactly the end of the growth. And on the other hand the motive of the profit still drives progress so the capitalist are the one who are looking for the profit so this will be one of the reason to the progress in the society, on the other side of the story it's mentioned that don't fear the robots because one extraordinary person can't be replace by 50 robots but 50 robots can be replace by one extraordinary person and also it's brought into the conclusion that more information, less Stuff this is what the future of the capitalism seems to be. So to put the end mark let me concluded it these words that change is not a viable at the moment but that does not mean one may not emerge in the next few decades.

*Corresponding author: Attaullah Hazrat, Lovely Professional University, Phagwara, India, Tel: 8001024431; E-mail: attauallah.hazrat@gmail.com

Received May 01, 2018; Accepted May 30, 2018; Published June 04, 2018

Citation: Hazrat A (2018) Capitalism: 50 Ideas You Really Need to Know. Int J Econ Manag Sci 7: 516. doi:10.4172/2162-6359.1000516

Copyright: (c) 2018 Hazrat A. This is an open-access article distributed under the terms of the Creative Commons Attribution License, which permits unrestricted use, distribution, and reproduction in any medium, provided the original author and source are credited. 